\title{
DANGEROUSNESS AND MENTAL ILLNESS SOME OBSERVATIONS ON THE DECISION TO RELEASE PERSONS ACQUITTED BY REASON OF INSANITY*
}

\author{
JOSEPH GOLDSTEIN† and JAY KATZ:
}

ON July 10, 1958, following the trial of Edith L. Hough for murder in the District of Columbia she was found not guilty by reason of insanity. ${ }^{1}$ Consequently she was committed to Saint Elizabeth's Hospital for treatment and custody. On October 20,1958, approximately three months later, Dr. Winfred Overholser, the hospital's superintendent, notified the trial court that "Miss Hough has now recovered sufficiently to be granted her conditional release ...."2 In response to an objection by the United States Attorney, a hearing was held before a trial judge who, after listening to the testimony of several psychiatrists, denied the release and directed the superintendent to discontinue his practice of allowing Miss Hough to leave the hospital for short periods during the day, except when in the custody of a hospital attendant. The judge found that she had not "recovered her sanity" and that it had not been established that she "will not in the reasonable future be dangerous to herself or others." 3 In reaching his decision, he found that the psychiatric testimony demonstrated that Miss Hough was still suffering from a schizophrenic reaction of the paranoid type and that she lacked any insight concerning the seriousness of the killing. He also took into account the shortness of the lapse of time since trial because he felt early release would be in conflict with the function of detention as a means of imposing punishment. ${ }^{4}$

These proceedings, which followed the verdict of acquittal by reason of insanity, were held pursuant to the District of Columbia statute which provides:

(d) If any person tried . . f for an offense ... is acquitted solely on the ground that he was insane at the time of its commission, the court shall order such person to be confined in a hospital for the mentally ill.

(e) Where any person has been confined in a hospital for the mentally ill pursuant to subsection (d) ... and the superintendent of such hospital certifies (1) that such person has recovered his sanity, (2) that, in the opinion of the superintendent, such person will not in the reasonable future

*This article, prepared at the invitation of the Editors of the Jonmal of Nervous and Mental Discases in response to Szasz, T. S., "Civil Liberties and Mental Illness," appears in a slightly condensed version concurrently in the Journal of Nervous and Mental Diseases.

TProfessor of Law, Yale University.

$\ddagger$ Associate Professor of Law, Associate Clinical Professor of Psychiatry, Yale University.

1. Brief for Appellee, p. 2, Hough v. United States, 271 F.2d 458 (D.C. Cir. 1959).

2. Ibid.

3. Hough v. United States, 271 F.2d 458, 461 (D.C. Cir. 1959).

4. Ibid; see note 9 infra and accompanying text. 
be dangerous to himself or others, and (3) in the opinion of the superintendent, the person is entitled to his unconditional release from the hospital, and such certificate is filed with ... the court in which the person was tried, and a copy thereof served on the United States Attorney . . . , such certificate shall be sufficient to authorize the court to order the unconditional release of the person so confined from further hospitalization at the expiration of fifteen days from the time said certificate was filed ... but the court in its discretion may, or upon objection of the United States [Attorney] ... shall, after due notice, hold a hearing at which evidence as to the mental condition of the person so confined may be submitted, including the testimony of one or more psychiatrists from said hospital. The court shall weigh the evidence and, if the court finds that such person has recovered his sanity and will not in the reasonable future be dangerous to himself or others, the court shall order such person unconditionally released .... Where, in the judgment of the superintendent of such hospital, a person confined under subsection (d) above is not in such condition as to warrant his unconditional release, but is in a condition to be conditionally released under supervision, and such certificate is filed ... [it] shall be sufficient to authorize the court to order the release ... under such conditions as the court shall see fit at the expiration of fifteen days from the time such certificate is filed and served .... Provided, That the provisions as to hearing prior to unconditional release shall also apply to conditional releases. ${ }^{5}$

The trial court's interpretation of this statute was reviewed, and reversed in part, by the Court of Appeals. ${ }^{6}$ It affirmed that even temporary leaves are regulated by the release statute and are to be treated as conditional releases. It reversed and ordered a new hearing on the ground that the lower court had ignored the essential distinction between the criteria for conditional and unconditional releases. ${ }^{7}$.The opinion emphasized the underlying policy of the statute, "to provide treatment and cure ${ }^{8}$ for the individual [as a 'patient' not a 'prisoner'] in a manner which affords reasonable assurance for the public safety."9

5. D.C. Code ANn. \$ 24-301 (Supp. VIII 1960). (Emphasis added.)

6. 271 F.2d 458.

7. Judge Bazelon indicated that an inconditional release will be granted where it appears that a patient has "recovered his sanity" and will not be "dangerous" to himself or others. On the other hand, he construed the statute to authorize conditional release where "insanity" and "dangerousness" persist, so long as the "proposed conditions" of release provide adequate external safeguards against his being "dangerous" to himself or others. See note 23 infra and accompanying text.

8. This may be a typographical error-"care" not "cure" was probably intended.

9. Hough v. United States, 271 F.2d 458, 461 (D.C. Cir. 1959). At a later period the court stated:

[W]e must reject the District Court's suggestion that appellant is a 'prisoner.' Nothing in the history of the statute-and nothing in its language-indicates that an individual committed to a mental hospital after acquittal of a crime by reason of insanity is other than a patient. ... Any preoccupation by the District Court with the need of punishment for crime is out of place in dealing with an individual who has been acquitted of the crime charged. 
The procedures described call into question the extent to which the community, through its legislature, courts, and mental hospitals, has a role to play in determining the detention or release of persons committed to mental institutions as a consequence of an acquittal by reason of insanity. This in turn raises the question of how and which community agencies are to share responsibility for such determinations. One body of opinion regards courts as peculiarly ill-suited to judge the readiness for release of persons acquitted by reason of insanity. The leading exponent of this position, Dr. Thomas Szasz, briefs the argument rhetorically:

[I] a psychiatrist in charge of a patient-who is not a convicted criminal !-regards him, in his own best judgment, as ready to leave a hospital ... how can he, in his professional conscience, let a court tell him that this he can not do? What is a psychiatrist "treating" the patient for, anyway? To make him a good "prisoner"? The farcical, were it not tragic, character of the notion of mental illness is well illustrated by these impossible dilemmas into which psychiatrists and lawyers place themselves, each other, their patients, and their clients.

Szasz seems to conclude that psychiatrists should be the exclusive judges of a patient's fitness for release from a mental institution to which he has been confined following a criminal trial:

[A]cquittal by reason of insanity, followed by automatic commitment, seems to lead by easy steps to preventive jailing (hospitalization) of persons because of their alleged future dangerousness .... . While the court has the right to order commitment, once a patient has been committed he comes under the jurisdiction of the hospital authorities. Hospital psychiatrists should be able to release the patient should they wish to do so. ${ }^{10}$

The Szasz position rests primarily on a question-begging assumption. That assumption, which will be discussed in an evaluation of the function of these release procedures, ${ }^{11}$ is that an acquittal by reason of insanity is equated with all other acquittals in the criminal process. ${ }^{12}$ For example, he maintains that

10. Szasz, Civil Libertics and Mental Illness-Some Observations on the Case of Miss Edith L. Hough, 131 J. of Nervous Diseases 58, 60 (1960).

11. See text following note 19 infra.

12. Historically this is not a valid assumption. See, e.g., Trial of James Hadfield, 27 State Trials 1281, 1353-55 (K.B. 1800).

Lord Kenyon.

With regard to the law, as it has been laid down, there can be no doubt upon earth; to be sure, if a man is in a deranged state of mind at the time, he is not criminally answerable for his acts; but the material part of this case is, whether at the very time when the act was committed this man's mind was sane. I confess, the facts proved by the witnesses (though some of them stand in near relationship to the prisoner, yet others do not) bring home conviction to one's mind, that at the time he committed this offence, and a most horrid one it is, he was in a very deranged state. I do not know that one can run the case very nicely; if you do run it very nicely, to be sure it is an acquittal. ... It is impossible that this man with safety to society can be suffered, supposing his misfortune is such, to be let loose upon the 
acquittals qualified "by reason of insanity" are equivalent to such outright unqualified acquittals as those based on the state's failure to establish that the individual charged committed the criminal act, or those based on findings that the acts complained of were excused for such accepted reasons as self-defense or official authorization. ${ }^{13}$ This assumption leads to the conclusion that persons such as Hough should be treated, so far as release procedures are concerned, as "bona fide innocent," 14 _ whatever that phrase may mean. It may mean, as Szasz seems to imply, that the community has no interest in the decision of when to release a person who, though acquitted, has demonstrated an ability, not merely a propensity, to commit dangerous acts. ${ }^{15}$

To determine criteria for release of those acquitted by reason of insanity, it becomes necessary first to establish the rationale for automatic commitment to

public. ... The prisoner, for his own sake, and for the sake of society at large, must not be discharged; for this case which concerns every man of every station, from the king upon the throne to the beggar at the gate; people of both sexes and of all ages may, in an unfortunate frantic hour, fall a sacrifice to this man, who is not under the guidance of sound reason; and therefore it is absolutely necessary for the safety of society, that he should be properly disposed of, all mercy and humanity being shown to this most unfortunate creature. But for the sake of the community, undoubtedly, he must somehow or other be taken care of, with all the attention and all the relief that can be afforded him.

For an interesting problem stemming from the difference between an acquittal by reason of insanity and an outright acquittal see Douglas v. United States, 239 F.2d 52, 54-55 (D.C. Cir. 1956) :

The contention on appeal is principally that evidence of the diseased mental condition of the accused requires us to hold that the trial judges should have directed verdicts of acquittal on the grounds of insanity. ...

The United States first suggests that such a direction would have been unconstitutional because if it had been given then the trial court would have been required to confine accused to St. Elizabeth's Hospital pursuant to section 24-301 of the Code, which would have deprived him of an opportunity to obtain an outright acquittal at the hands of the jury. But Douglas was not deprived of the opportunity to be acquitted outright because the cases went to the juries without the direction, and we accordingly need not decide the suggested constitutional question.

Id. at n.2:

If such a question exists in other circumstances the trial court may avoid it by allowing the jury to arrive at a verdict, as was here done, and then, if the verdict is one of guilty, entering a judgment of not guilty by reason of insanity notwithstanding the verdict should the court conclude that this were required. It is also probable in most instances that the constitutional difficulty could be avoided by an instruction that unless jury acquit outright, as they may, they should return a verdict of not guilty on the ground of insanity.

13. Szasz, supra note 10, at 59. Examples of authorized killings are the use of deadly force by a police officer to effect an arrest and by an executioner to administer the death penalty.

14. Szasz, supra note 10 , at 59 .

15. That an "acquittal by reason of insanity" implies commission of the unlawful act charged, is illustrated in the corresponding British terminology, "guilty but insane." Royar Commission on Capital Punishment, 1949-1953 Report at 156 (Cmd. 8392). 
a mental institution of a person thus acquitted. Logic would dictate, if Szasz is correct, that such persons, being "bona fide innocent," should be given their liberty subject only to the "civil" commitment procedures that are applicable to us all. But even assuming the validity of the "innocence" assumption and the logical conclusion therefrom, this does not move us very far. Whether commitments to a mental institution be via a "civil" or "criminal" route their functions are substantially the same: that "mentally ill" persons who evidence dangerousness to themselves or others be provided by the state with custody and care even if there is no known effective therapy or therapy is unavailable. Commitment procedures, however labelled, constitute a sanction, so far as the person confined is concerned, in the form of deprivation of liberty, at least to the extent that commitment is without regard to his "wishes."16 And a society free of such sanctions is difficult to visualize. It would require that each individual be so enlightened and free that he can become aware of his dangerousness and commit himself for the benefit of the community. Unlike a diagnosis of contagious tuberculosis (free of mental complications), cases involving mental disease may involve such distortions of reality that such awareness becomes even theoretically impossible.

Though the function of commitment to mental institutions is substantially the same, whether by a "civil" or "criminal" tribunal, the issues to be determined by each tribunal are different. In civil dispositions primary emphasis is placed on the current mental state of the individual to determine his commitability. In the criminal procedure, on the other hand, primary emphasis is focused on past mental state-at the time of the offense ${ }^{17}$-to determine

16. "Implicit in the word 'sanction' ... is involuntariness. In this context involuntariness is not treated as a psychological concept. Thus, for example, imprisonment is a sanction even if imposed on a person who commits a crime in order to be punished or in order to escape cold and hunger in the 'warmth' of a jail."

Goldstein, J., Police Discretion to Invoke the Criminal Process: Lozu-Visibility Decisions int the Administration of Justice, 69 YALE L.J. 543, 544 n.4 (1960).

Likewise, involuntary commitment of the mentally ill is a sanction even though it might be considered a secondary gain.

17. The determination of mental state at the time of the offense has been a time-honored element of insanity-defense tests and has been retained under Durham's jury instruction: "If you the jury believe beyond a reasonable doubt that the accused was not suffering from a diseased ... mental condition at the time he committed the criminal act charged, you may find him guilty." Durham v. United States, 214 F.2d 862, 875 (D.C. Cir. 1954). (Emphasis added.) Thus if the jury believes there was no mental disease at the time of offense it cannot proceed to determine the second major question, which under Durham is whether a causal relationship exists between the mental disease and the criminal act. Requiring focus on past mental state as well as causal relationship raises a series of questions peripheral to the main problems in this Article: Is it the function of concurrence in time of mental disease and criminal act to establish causal connection by presumption? If that is its function has it become an anomaly under Durham which also specifically requires the introduction of evidence and a determination on causal relationship between the mental disease and criminal act? Does the time requirement invite treating mental disease as a discrete phenomenon and thus preclude jury examination of causal relationship when it is found 
whether the offender shall be held subject to criminal sanctions; commitment is not directly an issue, but automatically follows an acquittal by reason of insanity. In effect, the defendant, by raising the defense of insanity-and he alone can raise it ${ }^{18}$ - postpones a determination of his present mental health and acknowledges the right of the state, upon accepting his plea, to detain him for diagnosis, care, and custody in a mental institution until certain specified conditions are met. And it should be noted that the defendant is presumed, or in such special proceedings as in the Hough case, actually found, to be sufficiently in contact with reality at the time of his trial to comprehend the nature and consequences of the variety of pleas and defenses available to him. ${ }^{10}$ Within these limits, commitment via the criminal process is initiated by the defendant and thus is more akin to "voluntary" than "involuntary" civil commitment.

From the time of commitment by either procedure the issues coalesce and the crucial problems emerge: who, what reasons, and what circumstances are to determine readiness for release? An examination of these problems requires, first of all, an analysis of how to define "dangerous to himself or others." In a democratic society, we believe, the function of delimiting dangerousness for release purposes belongs to the community. Translating community values and policies into an operational definition of dangerousness has been assigned initially to legislators and then to judges as construers of legislative determinations, and not to any particular administrative or professional group, including psychiatrists. This does not imply that psychiatrists as representatives of their profession or as members of the community have no duty to inform legislators and judges with regard to making such decisions as the meaning of "dangerous to himself or others." But it does imply that, when engaged as experts to participate in a hearing to determine an individual's readiness for release, they are not to define "dangerousness," but are, rather, to ascertain whether the individual is likely or not to engage in conduct which has been characterized as "dangerous." More specifically, in deciding whether individual " $x$ " is sufficiently "dangerous" not to be released, the psychiatrist as expert is to perform a purely diagnostic and prognostic function concerning the likely behavior of the

that at the time of the crime the accused was in remission or a lucid state? Would deletion of the time factor free psychiatrists of the impossible task of trying to establish mental state at a point in the past and instead leave them to testify as to the possible causal relationship between the underlying mental illness and the offense? For an illustration of the confusion between the causation element and the "at the time of the offense" requisite, see Dukes v. United States, No. 15277, D.C. Cir., Apr. 7, 1960.

18. Report of the Royal Commission on Capital Punishment, $\S \S 442-44$ (1953); Boyd iv. People, 108 Colo. 289, 294, 116 P.2d 193, 195 (1941). For a discussion of some of the policy issues involved, see Samuels, Can the Prosecution Allege That the Accused Is Sanc?, [1960] Crim. L.R. 435.

19. The question of the defendant's "sanity" may be in issue at several points in the criminal process. For example, the functions and implications of the test of competency to stand trial must be distinguished from those of the test of competency to commit a crime, i.e., the test of insanity as a defense. Both courts and psychiatrists frequently confuse these tests as well as others involving mental health. Durham v. United States, 237 F.2d 760 (D.C. Cir. 1956). 
person. But in deciding whether behavior " $x$ " (e.g., homosexual acts) is sufficiently "dangerous" to preclude release, the psychiatrist, as any other member of the community, may attempt to influence legislative and court decisions by expressing his value preferences. Making such a distinction among the roles psychiatrists may play at different points in the decision-making process should alert them, as well as all participants, to the extent to which value preferences permeate expert judgments. This, in turn, should prompt careful scrutiny of conclusionary statements qualified by such phrases as "on the basis of my professional opinion ...," expose those views which primarily reflect the psychiatrist's value preferences, and thus facilitate identification of decision points at which the psychiatrist should minimize his value orientation and at which the community has the right to establish policy. This is not to suggest that experts are to avoid, or can avoid, value judgments, but rather that they openly articulate them as such. ${ }^{20}$

While we share Szasz preference for minimizing deprivations of liberty as a criterion for assessing effectiveness of release procedures, we do not share his view that this value will best be protected by leaving solely to hospital psychiatrists the decision to release "should they wish to do so."21 The Szasz position, though unclear, seems to be that the psychiatrist's personal concept of "dangerousness" is not a variable in his decision to release and that "dangerousness" becomes operative only if the decision must be shared with the courts. Szasz seems to conclude that unless "dangerousness" is eliminated as a variable in the release-decision, "hospitalization" becames "preventive jailing," "patients" become "prisoners," "psychiatrists" become "jailers," and "judges" become "psychiatrists." Finally, he asserts that as a result of such mystical transformations the period of detention in mental institutions is extended for those acquitted by reason of insanity beyond that which would be generally the practice of psychiatrists acting alone. This assertion would be correct if, in making decisions to release, psychiatrists were trained and capable of excluding considerations, both conscious and unconscious, of a patient's "dangerousness" to himself or others. Szasz implies that this is his view by failing to identify the operative factors in what he calls a "psychiatrist ['s] ... own best judgment [with regard to] read [iness] to leave a hospital."22 But we find it difficult to believe that there

20. This is in keeping with the view expressed in the "Report of Panel on Science and Human Welfare" of the American Association for the Advancement of Science which says, in part:

With respect to the process of decision-making the scientist's role is simply that of an informed citizen. Like any other citizen; the scientist is free to express his opinions regarding alternative solutions for matters of public policy and will perhaps join with like-minded citizens in a group effort to foster the solution he prefers.

This role does not derive from the scientist's professional competence or obligations but only from his citizenship, and therefore it bears no direct relationship to his professional organizations.

N.Y. Times, July 8, 1960, § C, p. 6, cols. 5-6.

21. Szasz, supra note 10 , at 59 .

22. Id. at 60 . 
is not lurking in the quoted phrase recognition that psychiatrists are trained to, and do, take into account a patient's potential for doing harm to himself or others, however defined. The assertion that release would be expedited if psychiatrists had sole responsibility would, then, be correct only if it could be established, and for this there is no available data, (1) that among psychiatrists there is a consensus about the meaning and degree of "dangerousness" which precludes the release of a patient and (2) that compared with a court's concept of "dangerousness" a psychiatrist's is less severe or more permissive. Moreover, we know of no reason which even suggests a direct correlation between shorter periods of detention and leaving to each psychiatrist or hospital board alone the function of determining the meaning and degree of "dangerousness." Likewise, we find no reason which suggests a necessary correlation between longer periods of detention and a sharing of the release decision by psychiatrists and the courts.

The problem still remains of ascertaining and evaluating the process by which the crucial phrase "dangerous to himself or others" is to be given meaning. The task of defining and redefining, on the basis of actual cases, the meaning of "dangerousness" for release purposes has been delegated to the courts and mental health administrators. ${ }^{23}$ The desirability of this procedure, in terms of reducing threats to community well-being, maximizing individual dignity and, more particularly, minimizing deprivations of liberty, rests upon its capacity to force into view those rarely articulated factors which are crucial variables in psychiatric and judicial decisions to release or detain. Interaction in specific cases between the court's inherent interest in civil rights and the psychiatrists' primary interest in therapy will be openly define and redefine criteria for release which amalgamate and reflect these values. In addition, by this sharing of responsibility the traditional tasks of each discipline are restored and anxiety concerning community responses toward the release of any given individual can be minimized as a decisional factor. ${ }^{24}$ That this is more than mere fantasy

23. D.C. Code Ann. \$ 24-301 (Supp. VIII 1960).

24. Such anxiety is reflected in the following comment by a psychiatrist:

In the case of persons who have been arrested, particularly if charged with serious offenses, a greater degree of conservatism must be practised in the matter of release, in consideration of the attitudes of the public.

...

Thus, the hospital administration is torn between two urges, one, to release as many patients as possible, the other to pursue a reasonably conservative policy so as not to cause undue risk to the patient or to those about him. It may even be that we are too conservative!

Overholser, The Present Status of Problems of Release of Patients from Mental Hospitals, 29 Psychiatric QUARTERLy 372-80 (1955). For another psychiatric expression of other anxieties which seemed to suggest the desirability of court participation in the decision to release, see H.R. REP. No. 892, 84th Cong., 1st Sess. 14 (1955).

Dr. Guttmacher was asked the following question and gave the following answer:

Question: Do you think it advisable to have a statute which would provide that where a person is found not guilty of a crime solely by reason of insanity that he 
is illustrated by the appellate decision and subsequent events in the Hough case, as well as by other appellate interpretations of the statute.

The Hough decision, ${ }^{25}$ for example, did not close the door to liberty for Miss Hough. Rather, by enunciating guides for conditional release, which the appellate court had already established for unconditional release, ${ }^{26}$ it stimulated a series of interchanges between psychiatrist and lawyer which led to her conditional release. It reaffirmed, particularly for the trial judge, that length of confinement must not be related to punishment, and that consideration must only be given to a patient's condition, his need for treatment and the public's safety. Further, the decision advised that trial courts fulfill their role with regard to conditional releases simply by deciding whether "the evidence supports the hospital's determination that in all reasonable likelihood the patient's temporary absence from the hospital under specified conditions will not endanger others."27 As a consequence the Hough application was returned to the trial court for rehearing with specific provision for the introduction of supplementary evidence. Had a rehearing taken place without the introduction of new evidence it is more than likely that Miss Hough would have been denied release. Not only would it have been reasonable for the trial judge to have concluded on the basis of the testimony by Drs. Overholser and Karpman that she was still acutely psychotic, but also, especially from testimony by Dr. Karpman, that she was still "potentially dangerous" at this time. ${ }^{28}$ In addition, the

shall ... be released only on a certificate of the superintendent and a finding by the court that he is no longer a danger to himself or to the community?

Answer by Dr. Guttmacher:

[A]s a psychiatrist I have a great interest in the law's role that it plays in giving people and the community as a whole the feeling of security in these insecure times in which we live.

It is very important for people to feel comfortable and secure, . . .

It might be unnecessary, and, perhaps, some psychiatrists may feel in psychiatry -well, there are some people in state hospitals or Government institutions who are men with a conscience and they are not going to let some man run around the streets who is dangerous to people; I think in most cases-I would say in the vast majority of cases, or, perhaps, in all-that is true. On the other hand, I think this is a very special area and I think a man who is in a hospital because he has committed a crime, for which he has been exculpated, is a different individual from the individual who has been sent there as a mental case; and, therefore, I think, from a technical point of view, it might be necessary to have the court be the discharging agency.

The hearing reporter added: "The above statement was concurred in by Dr. Winfred Overholser, Superintendent of St. Elizabeth's Hospital."

25. Hough v. United States, 271 F.2d 458 (D.C. Cir. 1959).

26. Overholser v. Leach, 257 F.2d 667 (D.C. Cir. 1958); Rosenfield v. Overholser, 262 F.2d 34 (D.C. Cir. 1958).

27. Hough v. United States, 271 F.2d 458, 62 (D.C. Cir. 1958). (Emphasis added.)

28. Q. In your opinion is Edith L. Hough the aggressive type of paranoid? A. [Dr. Karpman] Yes, she is the aggressive type-as evidenced by the fact that she took measures of her own in killing the man. That is aggressiveness.

Q. In your opinion is an aggressive paranoid potentially dangerous? A. It is conceded universally an aggressive paranoid is dangerous. I would even say that univer- 
conditions for release proposed in the initial application were not sufficiently detailed to have permitted the judge to conclude that her release would not threaten public safety. But new evidence was introduced: the attorneys for Miss Hough, alerted by the experience at the first hearing and the appellate decision, challenged the reappointment of one of the psychiatrists as her examiner. They successfully and appropriately argued that because of his lifelong personal relationship with the Hough family and his personal feelings toward her it would be "impossible" for him to conduct an interview with her "in an atmosphere of mutual confidence and respect." 29 On the basis of new diagnostic evaluations by psychiatrists not personally involved with the Hough family, and a more detailed and meaningful presentation of the conditions specified for release, ${ }^{30}$ the trial judge, abiding by the new standards, granted her application for release. ${ }^{31}$

sally we think that any paranoid schizophrenic is potentially dangerous, because one can never tell when the meekness and submissiveness may suddenly turn around and become aggressive.

Q. Would you say Edith L. Hough at this time is potentially dangerous because she has schizophrenia, paranoid type? A. I would rather not answer this question directly. Ask me whether a paranoid schizophrenic is potentially dangerous, and I would say yes.

Q. You would say yes? A. Yes.

Hough v. United States, 271 F.2d 458, 468 (D.C. Cir. 1959).

29. Memorandum for Defendant, p. 4, United States v. Hough, Criminal No. 566-57, D.D.C., March 4, 1960. Order, United States v. Hough, Criminal No. 566-57, D.D.C., March 14, 1960.

30. Compare the plan submitted with the first application:

The plan under which we recommend that the conditional release be granted is that in accordance with the continuation of a total plan of rehabilitation Miss Hough be permitted to leave Saint Elizabeth's Hospital to go to the city of Washington, D.C., unaccompanied in an effort to obtain employment. It is recommended that this plan be carried out under very close hospital supervision and that she be subject at all times during the period of her conditional release to the supervision of the Social Service Department of Saint Elizabeth's Hospital and that she report to Saint Elizabeth's Hospital for examinations at such times as are designated by the authorities of Saint Elizabeth's Hospital.

Hough v. United States, 271 F.2d 458, 460 (D.C. Cir. 1959), with that for the second application:

Conditional release is recommended for the purpose of providing Miss Hough with the rehabilitative support which is considered psychiatrically indicated. Her mother's home is available to her, and the Social Service Department of the hospital has been made familiar with the case to provide supervision and support outside the hospital. Our plans include Miss Hough's returning to the hospital at weekly intervals to start for [sic] continued progress interviews with a staff psychiatrist familiar with her case. Work opportunities are presently available to her and are recommended as part of the treatment procedure. By a plan which involves Miss Hough's living with her mother, under the community support of Social Service, and with regular psychiatric interviews with a physician in whom she has demonstrated confidence, the public safety is assured.

Letter From W. Overholser to the United States District Court, Wash., D.C., Feb. 3, 1960.

31. Order of U.S. District Court, D.C., Criminal No. 566-57, May 3, 1960. 
The task of pouring substantive content into "potential 'danger," which the Court of Appeals for the District of Columbia has called "the heart of the test for retention or release," 32 has just begun. Some of the difficulties of definition are being uncovered not only in hearings to review applications for release submitted by the mental hospital, but also in habeas corpus proceedings in which the patient challenges the mental hospital's decision to continue confinement. Two major issues arise in these proceedings: one, what kinds of behavior are sufficiently threatening to be called "dangerous" and two, with what degree of certainty must the prognosis establish the likelihood of the kind or kinds of behavior designated "dangerous" occurring over what period of time.

With regard to the first issue, no criteria for "dangerousness" have been precisely articulated. The major problem is to identify criteria for evaluating the appropriateness of the many possible responses to the question posed: assuming mental illness requiring some form of treatment or care, what behavior should be classified dangerous enough to authorize deprivation of liberty by continued detention in a mental institution or by release under supervision? Dangerous behavior might be construed to include: (1) only the crime for which the insanity defense was successfully raised; (2) all crimes; (3) only felonious crimes (as opposed to misdemeanors) ; (4) only crimes for which a given maximum sentence or more is authorized; (5) only crimes categorized as violent; (6) only crimes categorized as harmful, physical or psychological, reparable or irreparable, to the victim; $(7)$ any conduct, even if not labelled criminal, categorized as violent, harmful, or threatening; $(8)$ any conduct which may provoke violent retaliatory acts; (9) any physical violence towards oneself; (10) any combination of these. More or other than the kind of offense for which the defense was raised was intended, for the statute specifically adds dangerousness to self as a basis for confinement. ${ }^{33}$ However, the D.C. court has not been challenged to further sort out the kinds of behavior to be classified as "dangerous" or to identify the values to be minimized and maximized. But it has already recognized the existence of these problems and has registered concern, for example, about the possible need for handling differently a patient with homicidal tendencies and one with a potential for forging checks. ${ }^{34}$ In the absence of court-created standards, the psychiatrist, it might be argued, is in an intolerable position. Actually the opposite is true, for he is presently free to apply for a patient's release on what has been called "his own best judgment." ${ }^{35}$ The psychiatrist, trained to seek release as soon as there is therapeutic indication for such a decision, can face the court with release applications involving a wide variety of behavioral pathology and thus prompt a series of

32. Ragsdale v. Overholser, No. 15437, D.C. Cir., June 23, 1960, at 10.

33. D.C. Code ANn. § 24-301 (Supp. VIII 1960).

34. Contrary to common belief, the defense of insanity is not limited to murder or to capital crimes. Ragsdale v. Overholser, U.S. Court of Appeals, D.C. Cir., No. 15437, June 23, 1960, pp. 10, 14; Overholser v. Russell, U.S. Court of Appeals, D.C. Cir. No. 15,536, June 23,1960 , p. 4.

35. Szasz, supra at note 10. 
decisions giving substantive content to "dangerousness." Coupled with patient challenges to denials for release by psychiatrists, these applications will permit court and psychiatrist to examine the values operative in their decisions. This in turn will permit the psychiatrist to more easily differentiate those aspects of his decision primarily determined by his expertise from those determined by his value preferences. ${ }^{36}$ In sharing with the court those aspects of decision in which community values are at stake the psychiatrist need neither be apologetic for having values, nor be misled into feeling that his role as expert is being usurped. ${ }^{37}$

With regard to the second issue, the D.C. court has emphasized from the very first construction of the statute that the psychiatrist is not required to "give an absolute guarantee that the patient will never again be mentally ill or dangerous. Reasonable foreseeability ... is the test." 38 But before such verbal admonitions are consistently applied, an understanding of their significance must be developed by providing, as is done by statute, an opportunity for case by case review of the action of the participants-the trial judge, the lawyer, and the psychiatrist. Through time the ambit of the degree of certainty possible will be more clearly communicated. This should eliminate such uncalled-for psychiatric responses as that given to a question in the first Hough hearing about the probability of the patient's doing "harm to herself or others?"

Well, there is that possibility with a great many people, some of whom have never been in mental hospitals. I can't make any guarantee about permanence, or even about the conduct. ${ }^{39}$

And minimally, in the event of such a response, a court should be alert to advise the psychiatric witness that certainty is not expected. Nor should courts expect a consensus among experts about the potential dangerousness of any patient. Whenever a consensus exists concerning the likelihood of "dangerous" behavior, a court must accept this view as a factor in its release determination. However, in the more likely absence of such a consensus among experts making prognoses about human conduct, a court must finally resolve for release purposes the differences of opinion about potential dangerousness uncovered

36. So far as the analyst is concerned Hartmann emphasizes:

There are ... the personal moral valuations of the analyst with respect to the material presented in analysis. One cannot deny the actuality of [this] factor-it is, above all, the natural outcome of the analyst's having his own value system .... But . . . this ... factor is best kept in the background in contacts with the patient; also, that in order to achieve this the analyst must be clearly aware of his own valuations and must know how to distinguish them from statements of fact. It has been doubted whether such reserve is really possible. Experience decides that it is, at least to a very considerable degree.

Hartanann, Psychoanalysis and Moral Values 54-55 (1960).

37. N.Y. Times, July 8,1960 , p. 6.

38. Rosenfield v. Overholser, 262 F.2d 34, 35 n.1 (D.C. Cir. 1958). (Emphasis added.)

39. Hough v. United States, 271 F.2d 458, 468 n.8 (D.C. Cir. 1959) (dissenting opinion). 
by the much maligned battle of the experts. ${ }^{40}$ This is as it should be. But without deluding themselves about their ability to predict, courts, in assuming this role, must continue to play the value-weighing function of balancing the unpredictable risks to individual liberty and public safety. ${ }^{41}$

But whatever role is assigned to lawyers and psychiatrists in the release process, there is in fact a real danger of unwarranted detention. The wording of the statute might invite an application which conflicts with the statute's therapeutic purpose and with the fundamental function of the criminal law to safeguard every individual from the imposition of sanctions solely for his potential dangerousness. ${ }^{42}$ Sickness of the individual and his need of treatment or care is the only justification for using "likelihood of dangerousness" as a basis for deprivation of liberty. ${ }^{43}$ Since "recovery of sanity" and the unlikelihood of dangerousness are requisites for release, the question arises: what disposition is to be made of those acquitted by reason of insanity who remain dangerouswhatever meaning will be given to that word-but who have "recovered sanity" at least to the extent that they could no longer be held had they been civilly

40. Diamond, The Fallacy of the Impartial Expert, 3 ArCHIves of CrIminal PsyChoDYNAMTCS 221 (1959).

41. Dr. Manfred S. Guttmacher in response to a request for his opinion of the first Hongh application for release said in part:

I don't run a hospital. I don't have the decisions to make as to when patients should be discharged or not. I don't for a moment feel that I have the right or the competence to preempt a judge's function in deciding what risks the community should take.

Brief for Appellee, p. 8, Hough v. United States, 271 F.2d 458 (D.C. Cir. 1959).

42. In a habeas corpus proceeding challenging detention for civil commitment, the court ordered release despite the following psychiatric report from Saint Elizabeth's Hospital:

Dallas $O$. Williams at the present time shows no evidence of active mental illness but ... he is potentially dangerous to others and if released is likely to repeat his patterns of criminal behavior, and might commit homicide.

The court said:

Many persons who are released to society upon completing the service of sentences in criminal cases are just as surely potential menaces to society as is this petitioner, having a similar pattern of anti-social behavior, lack of occupational adjustment, and absence of remorse or anxiety; yet the courts have no legal basis of ordering their continued confinement on mere apprehension of future unlawful acts, and must wait until another crime against society is committed or they are found insane in proper mental health proceedings before confinement may again be ordered.

In re Williams, 157 F. Supp. 871, 876 (D.D.C. 1958).

43. Judge Fahy in a concurring opinion goes further saying:

$[T]$ his mandatory commitment provision rests upon a supposition, namely, the necessity for treatment of the mental condition which led to the acquittal by reason of insanity. And this necessity for treatment presupposes in turn that treatment will be recorded.

Ragsdale v. Overholser, United States Court of Appeals Nọ, 15,437, June 23, 1960, pp. 13-14. 
committed? Continued detention would be the statutory answer.4 ${ }^{44}$ But to hold a patient solely for potential dangerousness would snap the thin line between detention for therapy and detention for retribution. ${ }^{45}$ Though the likelihood is not great that many cases will pose this issue, the possibility of it arising has increased under the Durham rule. ${ }^{46}$ The meaning of mental illness for the insanity defense has been construed under Durham to include "psychopathic and sociopathic personalities," 47 even though insanity for civil-commitment purposes excludes, except for the "sexual psychopath,"48 such personality disorders. ${ }^{49}$ Not to release such persons would in effect be to equate an undefined "dangerousness" with an undefined mental illness. Since there can be no such equation, a decision not to release solely on the basis of potential dangerousness would be like a decision not to discharge a tubercular patient-though no longer infectious-because he is a potential killer or check-forger. The court might, though it is doubtful, affirm the constitutionality of such denials on the theory that the patient "voluntarily" accepted these conditions for release by electing the defense of insanity. Realistically, this would stretch voluntariness to an absurd, though technically logical, point. Without declaring the statute unconstitutional, the court, more likely and more appropriately, would ignore

44. D.C. Code ANN. § 24-301 (Supp. VIII 1960).

45. Confusion in judicial thinking about this matter is illustrated by the following statement:

Two policies underly [sic] the distinction in treatment between the responsible and the non-responsible: (1) It is both wrong and foolish to punish where there is no blame and where punnishment cannot correct. (2) The community's security may be better protected by hospitalization . . . than by imprisonment.

Williams v. United States, 250 F.2d 19, 25-26 (D.C. Cir. 1957). (Emphasis added.)

'Punish' and 'punishment' are used in policy statement (1) to suggest different underlying meanings or concepts. The word is first used as a symbol of the vengeance or retribution function of the criminal law and then used as a symbol of the rehabilitation function. Query: If 'punishment,' however defined, were an effective rehabilitative device would the court find its use objectionable even if blameworthiness could not be established? Is involuntary confinement for an indefinite period in a mental hospital any less a deprivation, as the court seems to imply in policy statement (2), than involuntary confinement for a limited period in prison?

Goldstein, J., Police Discretion Not to Invoke the Criminal Process: Low-Visibility Decisions in the Administration of Justice, 69 YALE L.J. 543, 546 (1960).

Cf. Brief for Appellee, p. 19, Overholser v. Lynch, No. 15,859, D.C. Cir., 1960, stating: It is questionable if [St. Elizabeth's Hospita1] is a fit place for human habitation.

It is not unfair to state in the light of undisputed testimony upon the subject that large parts of St. Elizabeth's Hospital have been converted into detention centers, devoid of any therapeutic program worthy of the name.

46. Durham v. United States, 214 F.2d 862 (D.C. Cir. 1954).

47. Briscoe v. United States, 248 F.2d 640, 644 n.6 (D.C. Cir. 1957) ; Blocker v. United States, 274 F.2d 572, 573 (D.C. Cir. 1959); Weinofen, The Urge to Punish 87 (1956).

48. Miller v. Overholser, 206 F.2d 415 (D.C. Cir. 1953) ; Malone v. Overholzer, 93

F. Supp. 647 (D.D.C. 1950) ; D.C. CoDe ANN. § 22-3503(1) (1951).

49. In re Williams, 157 F. Supp. 871,876 (D.D.C. 1958). 
the "and" connecting the criteria for release. ${ }^{50}$ The D.C. court has already indicated that this would be done in the reverse situation, suggesting that release would be authorized for a patient no longer dangerous even "though he has not 'recovered his sanity." "a1 Better still, the legislature-here Congressshould amend the statute ${ }^{52}$ to release anyone who has "recovered sanity" and thus prohibit, if not preciude, deprivation of liberty without therapeutic justification. 53

Ultimately, if circularity of reasoning is to be avoided, many of the problems raised by this analysis of the decision to release persons acquitted by reason of insanity can only be resolved following a detailed reexamination of the function of the doctrine of criminal responsibility. The need for such a fundamental study is highlighted by what appears to be a fruitless and frustrating debate among and between lawyers and psychiatrists in search of a formula for insanity as a defense.

50. Under this construction and with current standards of civil commitment psychopaths, absolved of criminal responsibility under Durham, could not be detained in either prisons or hospitals. We recognize, of course, that civil commitment in practice may not work this way; either because the committing psychiatrist (1) deliberately manipulates nosological labels to implement his feelings, more as a member of the community than as an expert that "dangerous" people ought to be confined, or (2) makes a longtitudinal diagnosis which suggests or reveals an underlying psychosis though a diagnosis in terms of current symptomatology would not. Williams v. United States, 250 F.2d 19 (D.C. Cir. 1957) ; In re Williams, 157 F. Supp. 871 (D.D.C. 1958). See notes 42 \& 45 supra.

51. Hough v. United States, 271 F.2d 458 (D.C. Cir. 1959); Overholser v. Leach, 257 F.2d 667, 670 (D.C. Cir. 1958) ; Overholser v. Russel, United States Court of Appeals No. 15,536, June 23, 1960.

52. D.C. Code ANN. \$ 24-301 (Supp. VIII 1960).

53. The New York legislature has taken a contrary position. See N.Y. Code CRIM. PRoc. § 454(3) (6) which provides that a person committed pursuant to an acquittal by reason of insanity shall be discharged or conditionally released only when this may be done without danger to himself or others, and that persons so committed may be held in custody either in an institution of the department of mental hygiene or of the department of correction. See text and note 45 supra. 